\title{
Phytosociological features and threat categorization of A. heterophyllum Wall. ex Royle and A. ferox Wall. ex Ser. in Kumaun Himalaya
}

\author{
Deepika Bhatt ${ }^{1}$, G. C. Joshi ${ }^{1}$, Ravi Kumar ${ }^{1}$ and L. M. Tewari ${ }^{2}$ \\ ${ }^{1}$ Regional research Institute of Himalayan Flora, (CCRAS) Tarikhet, Ranikhet -263 663, Uttarakhand, India. \\ ${ }^{2}$ Department of Botany, D. S. B. Campus, Nainital, Uttarakhand, India.
}

Accepted 7 January, 2014

\begin{abstract}
Alpine and subalpine regions of Kumaun Himalaya were surveyed qualitatively and quantitatively for the population study to determine the status of Aconitum ferox and A. heterophyllum. Low population density across the surveyed populations and restricted distribution to specific pockets indicates poor availability of the species in the study area. Illegal and over exploitation of these species pose threat to their existence. The present study clarifies the population structure of identified aconite species in Kumaun Himalaya. Observations reveal that on the basis of six attributes (that is habitat preference, distribution range, population size, use pattern, extraction trend, native and endemic species) used to assign threat categories, both the Aconitum species are endangered.
\end{abstract}

Key words: Endangered, Himalaya, Aconitum heterophyllum, Aconitum ferox, medicinal plant.

\section{INTRODUCTION}

Since time immemorial, Himalaya is famous for its rich plant biodiversity including a wide range of medicinal and aromatic plants. The variety of soils, topography and climatic conditions of the region provide very congenial conditions for growth and development of many therapeutically important medicinal plant species (Rawat, 2005). However, most of these MAPs are experiencing habitat destruction due to unscientific, over and irregular exploitation of plants, which resulted in very fast depletion as well as extinction of some medicinally important plant species (Rau, 1975). There are many species which have become threatened in several tracts and are found only in inaccessible hilly areas. Recently, CAMP (2003) assessed threat status of plant species in Uttarakhand in which Aconitum ferox Wall. ex Ser. and Aconitum heterophyllum Wall. ex Royle were assigned the critically endangered and vulnerable status respectively. Aconites are widely recognized for their medicinal importance in
Indian System of Medicine (ISM). According to Red List Categories published by IUCN (1993), threatened species are having small geographic area, narrow habitat specificity, commonly sparse and geographically restricted to special habitat.

A. ferox (Vern. Meetha-Vish, Vatsanabh) (Plate 1) and $A$. heterophyllum (Vern. Atees) (Plate 2) belongs to the family Ranunculaceae. $A$. ferox is an erect herb with glabrescent stem and long, broadly ovate, cordate leaves. Distribution of this species is found between 3000 - 3600 ma.s.I. in Kumaun Himalaya (Figure 1). Tubers of the species are collected in the month of SeptemberOctober and are used as remedy for stomach ache, fever, and indigestion by the aboriginals. $A$. heterophyllum (Vern. Atees) is an erect, tuberous herb found at the same elevation of $A$. ferox (Figure 1). Tubers are collected and dried during September-October and are used in diseases like diarrhea, fever, general body 

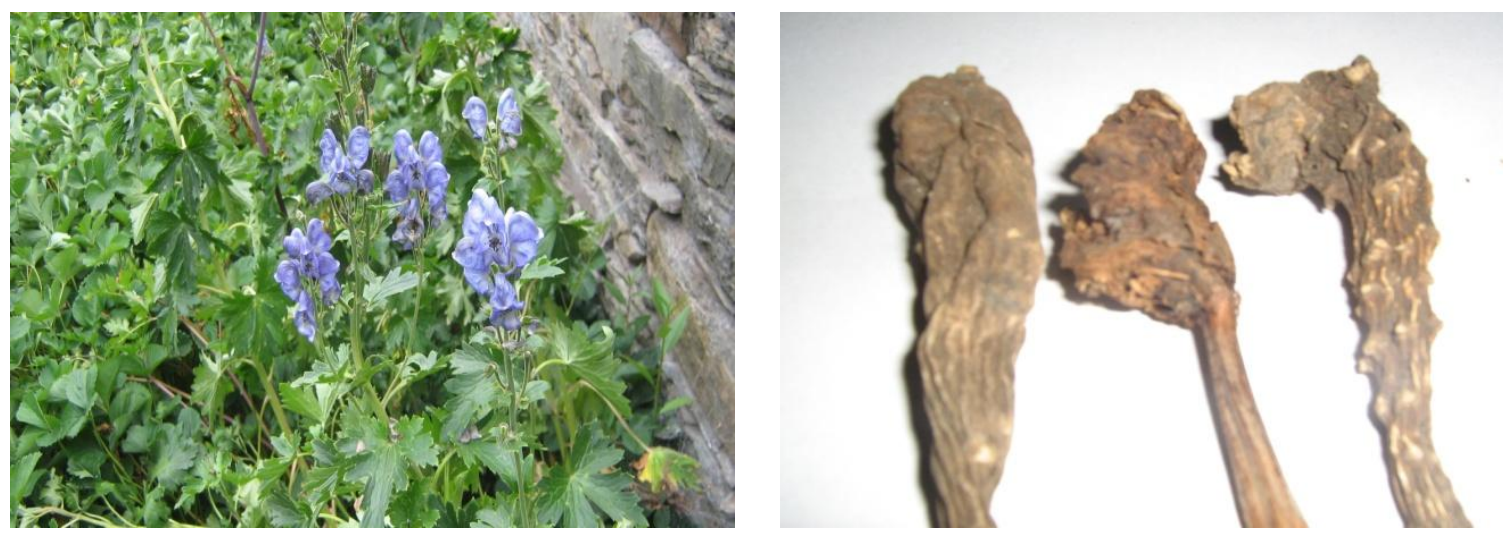

Plate 1. Aconitum ferox Wall. ex Ser.
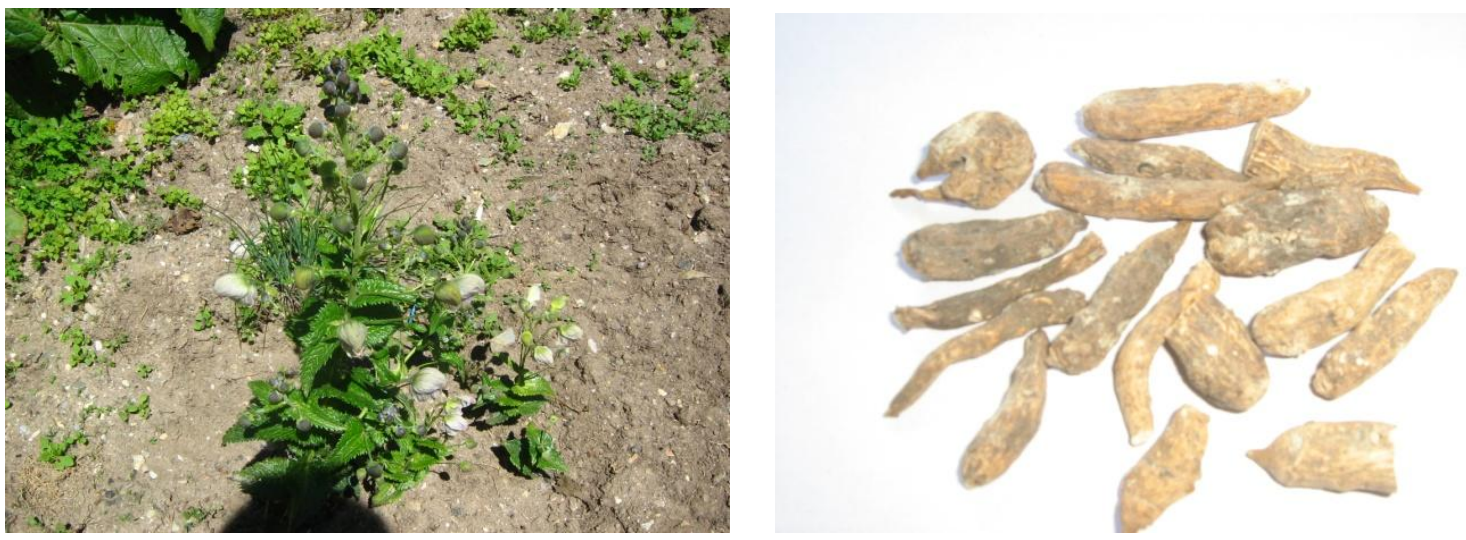

Plate 2. Aconitum heterophyllum Wall. ex Royle.

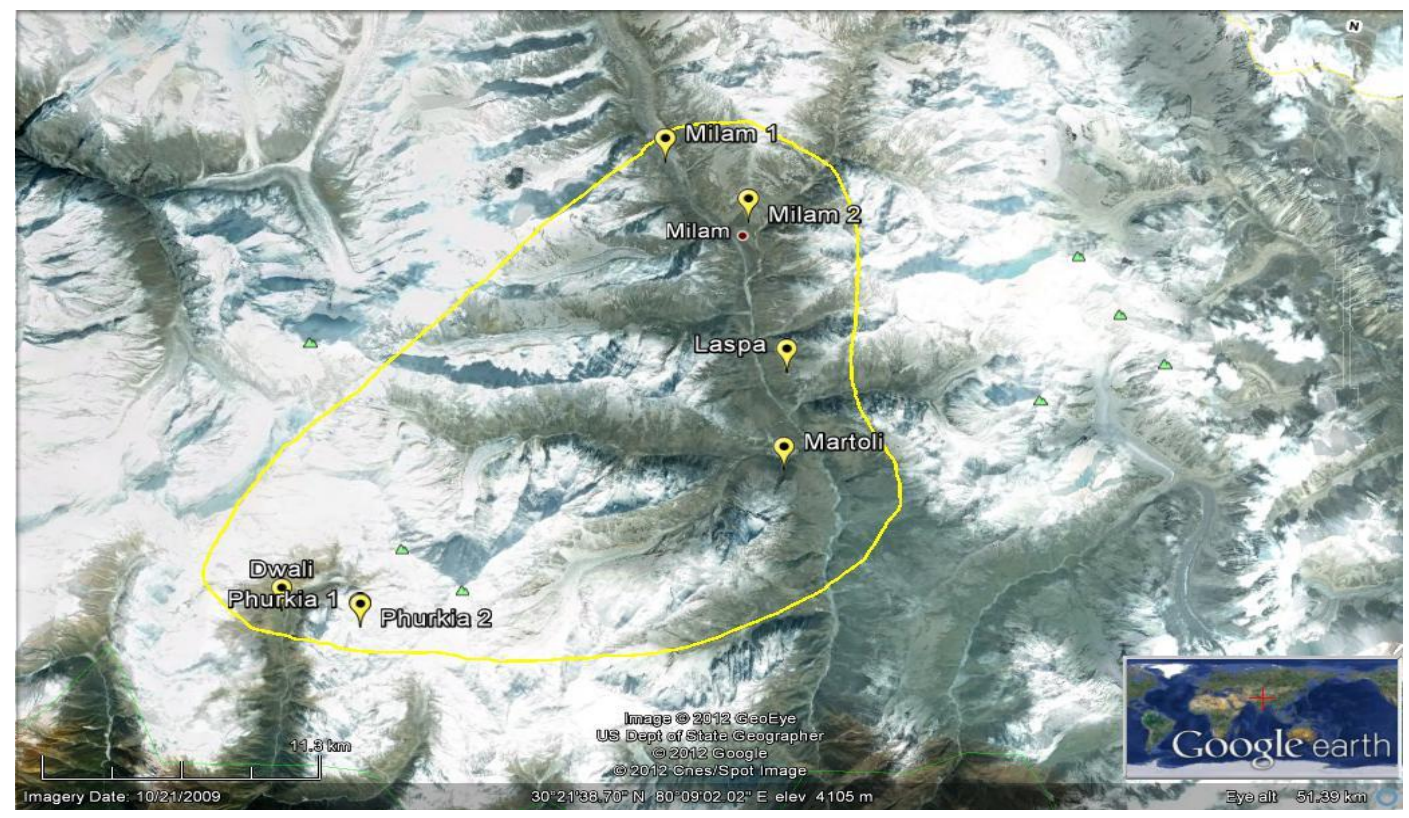

Figure 1. Map of study sites. 
ache and also used as an aphrodisiac.

Till date, any assessment of threat categories to species in IHR is generally based on qualitative observations (Pangtey and Samant, 1988; Samant et al., 1993, 1996 a,b; Pandey and Well, 1997; Kala et al., 1998; Uniyal et al., 2002). Only a few studies have considered both qualitative and quantitative attributes for the assessment of species status (Airi et al., 2000; Nautiyal et al., 2002; Bhatt et al., 2007).

As quantitative infor-mation on a species plays a vital role in formulating a conservation plan and in understanding the ecology of the species (Uniyal et al., 2002), thus, the aim of the study was: a detailed survey of these aconites for quan-titative analysis throughout the Kumaun region. This is an attempt to provide quantitative details of $A$. ferox Wall. ex Ser. and $A$. heterophyllum Wall. ex Royle through assessment of the distribution patterns and quantum of availability. Also, it will provide essentially simple and assimilated data on current status of species population which can be used for assigning the categories of threat as suggested under IUCN Red List Categories (1993).

\section{MATERIALS AND METHODS}

\section{Study area and methods}

\section{Field study}

For the population assessment of these two species and their status in the study area fields surveys, vegetation sampling, vegetation analysis and quantitative analysis was done in 7 populations in sub alpine and alpine region, within three years from April 2008 to April 2011, during the peak season of flowering. The area surveyed included: Milam (Moraine) (P1- $4250 \mathrm{~m}$ ), Milam (Fallow fields) (P2- $4178 \mathrm{~m}$ ), Martoli (Pasture) (P3- $3974 \mathrm{~m}$ ) and Laspa (P4-3669 $\mathrm{m}$ ) and adjacent areas in Pithoragarh district; Phurkia (Scrub) (P5- $3260 \mathrm{~m}$ ), Phurkia (Pasture) (P6-3150 m), Dwali (P7- $2790 \mathrm{~m}$ ) in Bageshwar district (Figure 1).

\section{Vegetation sampling and analysis}

For the phytosociological study in every study sites, 30 quadrats of $1 \times 1 \mathrm{~m}(1 \mathrm{sq} \mathrm{m})$ size at different altitudinal range were randomly laid (Misra, 1968). For population analysis and threat category determination, strands of $100 \times 100 \mathrm{~m}^{2}$ were identified and marked on each site. Vegetation sampling was conducted through vertical transect method (Michel, 1990). Since the distribution range is narrow and topography is diverse, approximately $60 \mathrm{~m}$ long and 30 $\mathrm{m}$ wide transect was laid in each strand. Transect were divided into 3 plots of $20 \times 10 \mathrm{~m}$ size as replicates and 10 quadrats of $1 \times 1 \mathrm{~m}$ were laid randomly in each plot following Kershaw 1973. The threat category of a species was identified using six attributes (habitat preference, distribution range, population size, use pattern, extraction trend, native and endemic species) and following Samant et al. (1998) and Ved et al. (2003).

\section{Quantitative analysis}

The quantitative analysis such as density, frequency, and abundance of tree, shrubs and herbs species were determined as per Curtis and McIntosh (1950).

Total number of quadrats in which species occurred

Frequency $=$

Total number of quadrats studied

Total number of individuals of a species in all quadrats

Density =

Total number of quadrats studied

Total number of individuals of a species in all quadrats

Abundance $=$

Total number of quadrats in which the species occurred

$\mathrm{A} / \mathrm{F}$ ratio $=\frac{\text { Abundance }}{\text { Frequency }}$

Pattern of the species was analyzed on the basis of abundance to frequency $(A / F)$ ratio. Similarly relative values of frequency, density and dominance and Importance Value Index (IVI) were computed following the methods of Curtis (1959) as:

Relative frequency $=\frac{\text { Percent frequency of species }}{\text { Total percent frequency of community }} \times 100$
Relative density $=\frac{\text { Density of species }}{\text { Total density of the community }} \times 100$
Relative dominance $=\frac{\text { Total basal cover of species }}{\text { Total basal cover of the community }} \times 100$

Basal area $=\frac{(\text { Cbh }) 2}{4 \pi}$

Total basal cover $($ TBC) $=$ Mean basal cover $\square$ Density Importance Value Index (IVI) = Relative frequency + Relative density + Relative dominance.

The species richness of the vascular plants was computed by using the method 'Menhinick's richness index ( $\left.D_{M n}\right)$ (Whittaker, 1977). The diversity index (H), was calculated by using ShannonWiener information Index (Shannon and Wiener, 1963). The concentration of dominance (Cd) was calculated by Simpson's Index (Simpson 1949).

\section{Statistical techniques}

Correlation between Density and Important value index (IVI) of the two species is computed through Carl Pearson's method. Regression has been subjected to density and important value index (IVI) of the study area. A curve that describes the distribution of probability over the values of a random variable is drawn with the help of Statistical Package for the Social Sciences (SPSS) software. Phytograph of both plant species is plotted to describe the phytosociological status of the plant using window 2007 'EXCEL' software.

\section{RESULTS}

\section{Occurrence and availability}

Performance details, at different altitudes, of identified taxa A. ferox is presented in Table 1. A.ferox grows well 
Table 1. Phytosociological characters of A.ferox at different sites in Kumaun Himalaya.

\begin{tabular}{|c|c|c|c|c|c|c|c|c|}
\hline Population & $\begin{array}{l}\text { Altitude } \\
\text { (amsl) }\end{array}$ & $\begin{array}{l}\text { Habitat } \\
\text { characteristics }\end{array}$ & $\begin{array}{l}\text { Frequency } \\
(\%)\end{array}$ & $\begin{array}{l}\text { Density } \\
\left(\operatorname{lnd} / \mathrm{m}^{2}\right)\end{array}$ & Abundance & $\begin{array}{l}\text { TBC } \\
\left(\mathrm{cm}^{2} \mathrm{~m}^{-2}\right)\end{array}$ & IVI & $\begin{array}{l}\text { Distribution } \\
\text { Pattern } \\
\text { (A/F ratio) } \\
\end{array}$ \\
\hline P1 & 4250 & $\begin{array}{l}\text { Glacial reverine and rocky moist } \\
\text { area }\end{array}$ & $50.00 \pm 3.00$ & $0.83 \pm 0.16$ & $1.14 \pm 0.08$ & $0.39 \pm 0.20$ & $6.63 \pm 0.21$ & 0.023 \\
\hline P2 & 4178 & $\begin{array}{l}\begin{array}{l}\text { Alpine dry } \\
\text { nubigena- } \\
\text { community }\end{array} \\
\text { Kobresia }\end{array} \quad \begin{array}{r}\text { Carex } \\
\text { duthiei }\end{array}$ & $56.67 \pm 1.06$ & $0.93 \pm 0.13$ & $1.22 \pm 0.07$ & $0.50 \pm 0.05$ & $7.58 \pm 0.08$ & 0.022 \\
\hline P3 & 3974 & Open grassy alpine slope & $46.67 \pm 1.09$ & $0.77 \pm 0.18$ & $0.92 \pm 0.14$ & $0.52 \pm 0.06$ & $6.91 \pm 0.13$ & 0.020 \\
\hline P4 & 3669 & Shady moist alpine slopes & $40.00 \pm 1.00$ & $0.60 \pm 0.16$ & $0.75 \pm 0.07$ & $0.42 \pm 0.04$ & $5.44 \pm 0.26$ & 0.019 \\
\hline P5 & 3260 & Shady moist alpine slopes & $60.00 \pm 0.33$ & $1.10 \pm 0.16$ & $1.83 \pm 0.15$ & $0.49 \pm 0.15$ & $7.75 \pm 0.40$ & 0.030 \\
\hline P6 & 3150 & $\begin{array}{l}\text { Forest edges, Rhododendron } \\
\text { Forest margin }\end{array}$ & $56.67 \pm 1.13$ & $1.07 \pm 0.06$ & $1.88 \pm 0.11$ & $0.54 \pm 0.29$ & $9.29 \pm 0.14$ & 0.033 \\
\hline P7 & 2790 & $\begin{array}{l}\text { Moist rock, Quercus- Abies } \\
\text { forest margins }\end{array}$ & $63.33 \pm 0.69$ & $0.93 \pm 0.09$ & $1.47 \pm 0.27$ & $0.37 \pm 0.15$ & $8.31 \pm 0.07$ & 0.023 \\
\hline
\end{tabular}

P1, Milam (Moraine); P2, Milam (Fellow Fields); P3, Martoli; P4, Laspa; P5, Phurkia (Pasture); P6, Phurkia (Scrub); P7, Dwali.

in Shady moist alpine slopes. The density of $A . f$ erox ranged between 0.60 individual / $\mathrm{m}^{2}(\mathrm{P} 4)$ to 1.10 individual $/ \mathrm{m}^{2}$ (P5). The frequency of occurrence was varied between $40 \%$ (P4) to $63.33 \%$ (P7) and comparable to other associated species. The abundance to frequency (A/F) ratio of $A$. ferox revealed that species was distributed regularly in the five populations $(\mathrm{P} 1, \mathrm{P} 2, \mathrm{P} 3, \mathrm{P} 4$ and P7). Few other populations, P5 and P6 showed random distribution patterns (Table 1 and Figure 2).

A. heterophyllum showed best growth in natural habitat at two sites: P1 and P4. The density of $A$. heterophyllum varied between 0.21 individual / $\mathrm{m} 2$ (P4) to 0.62 individual / m2 (P6). The frequency of occurrence was relatively better $(60 \%$ for P3 to $76.67 \%$ for P2, P4, and P7). The species largely prefers the southeast facing slope. Distribution pattern of $A$. heterophyllum shows that the species was distributed regularly in most of the populations (P2, P4, P5, P6 and P7); only two populations ( $\mathrm{P} 1, \mathrm{P} 3)$ showed random distribution (Table 2 and Figure 3)

\section{A. heterophyllum}

Considering that the IVI provides an excellent marker for determining the status of distribution and availability across varying environmental and biotic conditions (Negi et al., 1992; Ram and Arya, 1991), value of both identified taxa was compared. Values varied from one population to other. This difference can be attributed to varying species number, topography, biotic and abiotic interferences in community (Nautiyal, 1996). A ferox had maximum IVI at P6 (9.29) in forest edges, Rhododendron forest margin while it was recorded minimum in P4 (5.44) where habitat was shady moist alpine slope. $A$. heterophyllum showed maximum IVI value of 9.70 in $\mathrm{P} 2$ and lowest value of 7.76 in P5. Phytograph of each species (Figures 4 and 5) was drawn to clarify the phytosociological attribute of the species.

\section{Diversity Indices}

Table 3 depicts the plant species richness (Mel), Shannon- Weiner diversity index $\left(\mathrm{H}^{\prime}\right)$, and Concentration of dominance (Cd) of seven sampling plots in different forest patches of study area for both species. The adjusted ShannonWiener Index is the percent of the maximum possible diversity. It varied from $2.96-2.97$ for $A$. ferox and 2.89 - 2.91 for $A$. heterophyllum in different alpine habitats. The low diversity was in single species dominant and low grazing pressure communities, and high in the case of moderately grazed communities. The Menhinick's richness 


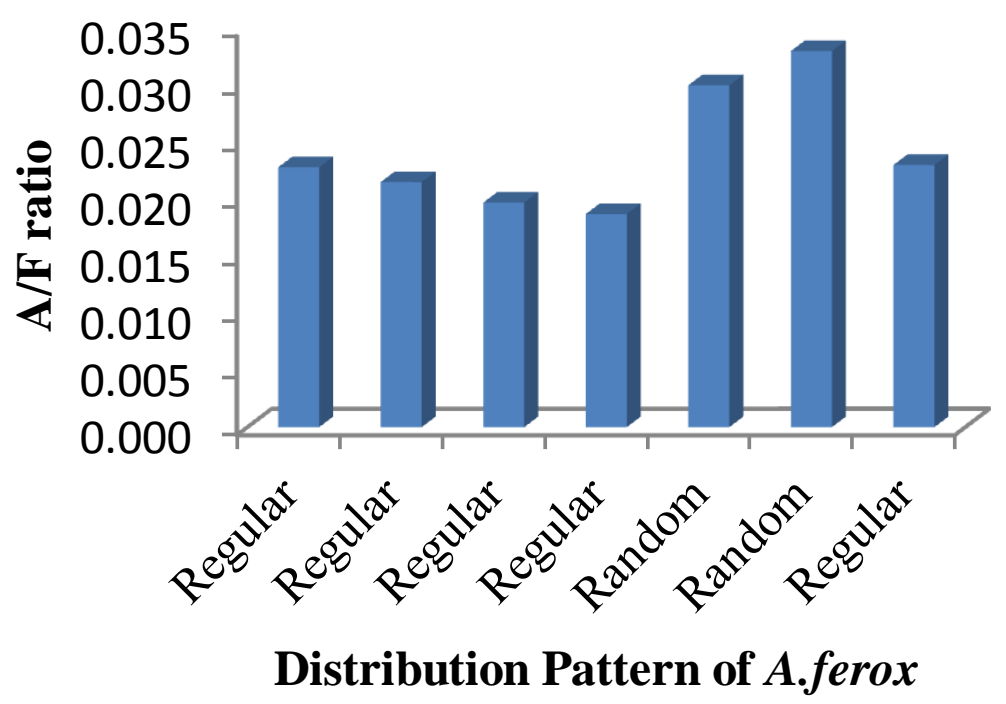

Figure 2. Distribution Pattern of $A$. ferox.

varied from $0.49-0.57$ for $A$. ferox and $0.55-0.60$ for $A$. heterophyllum. Concentration of dominance represents the different biodiversity. It ranges from $0.052-0.054$ for $A$. ferox and $0.056-0.058$ for $A$. heterophyllum.

In order to check the dispersal of both species, the normal probability curve (NPC) has been plotted for species richness against normal distribution. The plotted points do not fit the line well, and curve away from it in places; it is a non normal distribution. It indicates that the distribution of both species in selected sites is skew (Figures 6 and 7).

\section{Regression}

Regression has been subjected to density and IVI of both the species. Significant positive correlation was found between both the characters that density and IVI at $p<0.001$ level of significance. Density was taken as independent variable and IVI as dependent. Regression equation for A.ferox is $y=6.2195 x+1.8808$, $R$ square is 0.7621 . For $A$. heterophyllum regression equation was $y$ $=0.3728 x+8.6001, R$ square is 0.0043 . From this equation relation between density and IVI can be calculated in the natural habitat.

\section{Threat categorization}

An area-specific threat categorization of species is very important for short or long-term management planning. The information, thus generated, has immense potential for contributing in threat categorization, conservation and management of threatened plant species (Hutchings, 1991). On the basis of the above interpretations and following Samant et al. (1998) and Ved et al. (2003), threat category of the species was identified using six attributes (habitat preference, distribution range, population size, use pattern, extraction trend, native and endemic species). In the present study, both the species of aconite, namely $A$. ferox and $A$. heterophyllum seems to be endangered in Kumaun Himalaya while assessed as critically endangered and vulnerable by CAMP (2003). These observations would also be helpful in determining the status of other species and can be applied for conservation strategies.

\section{DISCUSSION}

Low seed viability, obstruction of reproductive phases by juvenile, fronts and early snow fall coupled with biotic interference prevents seed maturation and reduced plant population in most of alpine vegetation (Pandey et al., 1997); hence they emerge through underground parenting organs (tubers). Studies on quantitative assessment play a vital role in the ecology of the species (Uniyal et al., 2002). It helps in determining the performance of populations under different sets of conditions and provides desired information about the specialized ecological requirements of a taxon (Kaul and Handa, 2001). The information, thus generated quantitatively clears that population of $A$. ferox and $A$. heterophyllum is severely fragmented (low population density and restricted distribution of species). This has conservation implications because species with specific habitat requirements have greater possibilities of extinction than species with a broad habitat range. In addition, a minimum population size is required for the long-term viability of threatened species (Cunningham and Saigo, 1999). Considering the higher frequency of occurrence in some populations is indicative that species 
Table 2. Phytosociological characters of $A$.heterophyllum at different sites in Kumaun Himalaya.

\begin{tabular}{|c|c|c|c|c|c|c|c|c|}
\hline Population & $\begin{array}{l}\text { Altitude } \\
\text { (amsl) }\end{array}$ & $\begin{array}{l}\text { Habitat } \\
\text { characteristics }\end{array}$ & $\begin{array}{l}\text { Frequency } \\
(\%)\end{array}$ & $\begin{array}{l}\text { Density } \\
\left(\text { Ind } / \mathrm{m}^{2}\right)\end{array}$ & Abundance & $\begin{array}{l}\text { TBC } \\
\left(\mathrm{cm}^{2} \mathrm{~m}^{-2}\right)\end{array}$ & IVI & $\begin{array}{l}\text { Distribution Pattern } \\
\text { (A/F ratio) }\end{array}$ \\
\hline $\mathrm{P} 1$ & 4250 & Glacial revarine and rocky moist area & $63.33 \pm 0.98$ & $1.07 \pm 0.21$ & $1.68 \pm 0.11$ & $0.40 \pm 0.06$ & $9.29 \pm 1.82$ & 0.026 \\
\hline $\mathrm{P} 2$ & 4178 & $\begin{array}{l}\text { Alpine dry scrub, Carex nubigena- Kobresia } \\
\text { duthiei community }\end{array}$ & $76.67 \pm 3.34$ & $0.93 \pm 0.07$ & $1.22 \pm 0.09$ & $0.54 \pm 0.03$ & $9.70 \pm 1.02$ & 0.016 \\
\hline P3 & 3974 & Open grassy alpine slope & $60.00 \pm 2.00$ & $1.03 \pm 0.13$ & $1.72 \pm 0.08$ & $0.38 \pm 0.05$ & $8.06 \pm 1.01$ & 0.028 \\
\hline P4 & 3669 & Shady moist alpine slopes & $76.67 \pm 3.32$ & $1.07 \pm 0.34$ & $1.39 \pm 0.15$ & $0.21 \pm 0.05$ & $8.72 \pm 0.28$ & 0.018 \\
\hline P5 & 3260 & Shady moist alpine slopes & $66.67 \pm 0.76$ & $0.77 \pm 0.13$ & $1.15 \pm 0.09$ & $0.30 \pm 0.05$ & $7.76 \pm 1.37$ & 0.017 \\
\hline P6 & 3150 & Forest edges, Rhododendron Forest margin & $70.00 \pm 1.13$ & $0.73 \pm 0.09$ & $1.05 \pm 0.10$ & $0.62 \pm 0.06$ & $9.46 \pm 0.86$ & 0.015 \\
\hline P7 & 2790 & Moist rock, Quercus- Abies forest margins & $76.67 \pm 1.20$ & $0.97 \pm 0.18$ & $1.26 \pm 0.09$ & $0.49 \pm 0.06$ & $9.66 \pm 1.00$ & 0.016 \\
\hline
\end{tabular}

P1, Milam (Moraine); P2, Milam (Fellow Fields); P3, Martoli; P4, Laspa; P5, Phurkia (Pasture); P6, Phurkia (Scrub); P7, Dwali.

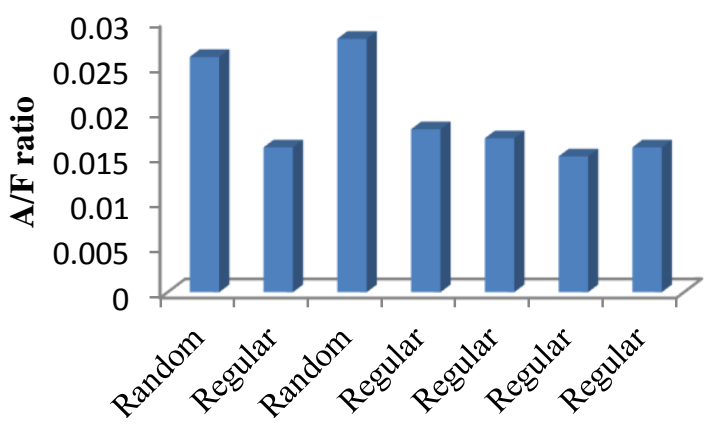

Figure 3. Distribution Pattern of $A$. heterophyllum.

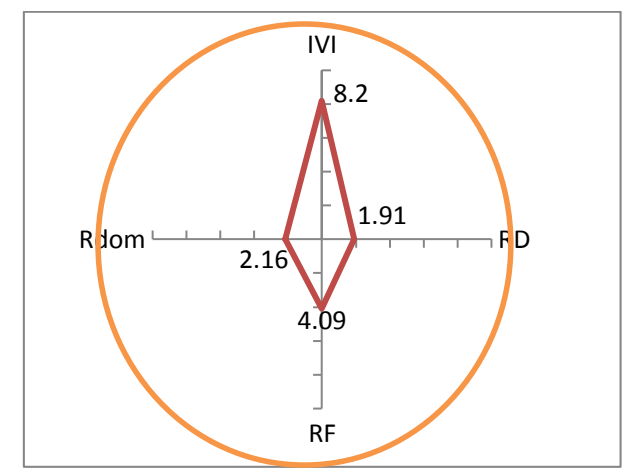

Figure 4. Phytograph of $A$. ferox. 


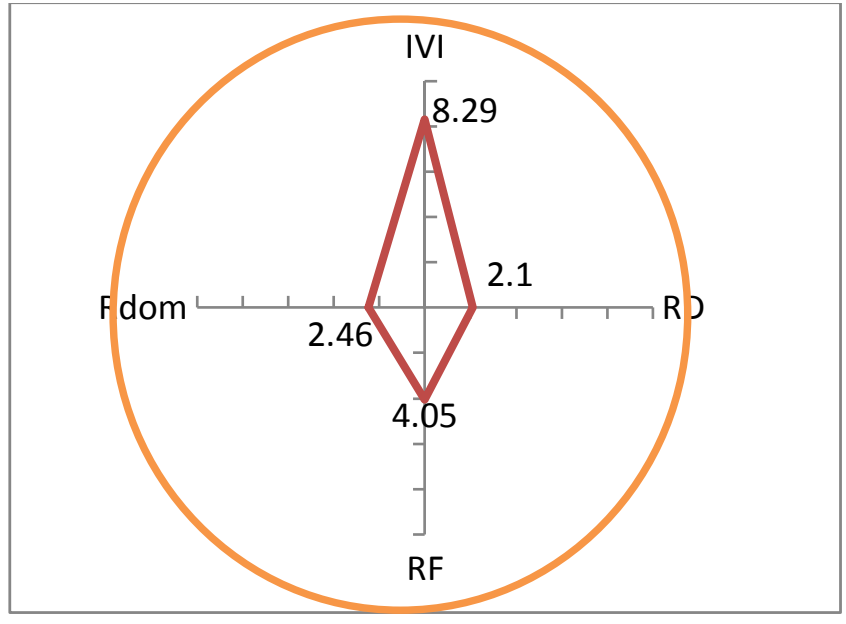

Figure 5. Phytograph of A.heterophyllum.

Table 3. Diversity indices of sampling plots for A.ferox and A. heterophyllum.

\begin{tabular}{lcccccc}
\hline \multirow{2}{*}{ Site code } & \multicolumn{3}{c}{ A. ferox } & \multicolumn{3}{c}{ A. heterophyllum } \\
\cline { 2 - 7 } & Cd & H'$^{\prime}$ & Mel & Cd & H'$^{\prime}$ & Mel \\
\hline P1 & 0.052 & 2.97 & 0.51 & 0.056 & 2.91 & 0.57 \\
P2 & 0.052 & 2.96 & 0.49 & 0.056 & 2.91 & 0.58 \\
P3 & 0.054 & 2.97 & 0.57 & 0.056 & 2.91 & 0.57 \\
P4 & 0.052 & 2.97 & 0.53 & 0.056 & 2.90 & 0.60 \\
P5 & 0.053 & 2.96 & 0.54 & 0.056 & 2.91 & 0.56 \\
P6 & 0.053 & 2.96 & 0.51 & 0.056 & 2.91 & 0.55 \\
P7 & 0.052 & 2.97 & 0.50 & 0.058 & 2.89 & 0.57 \\
\hline
\end{tabular}

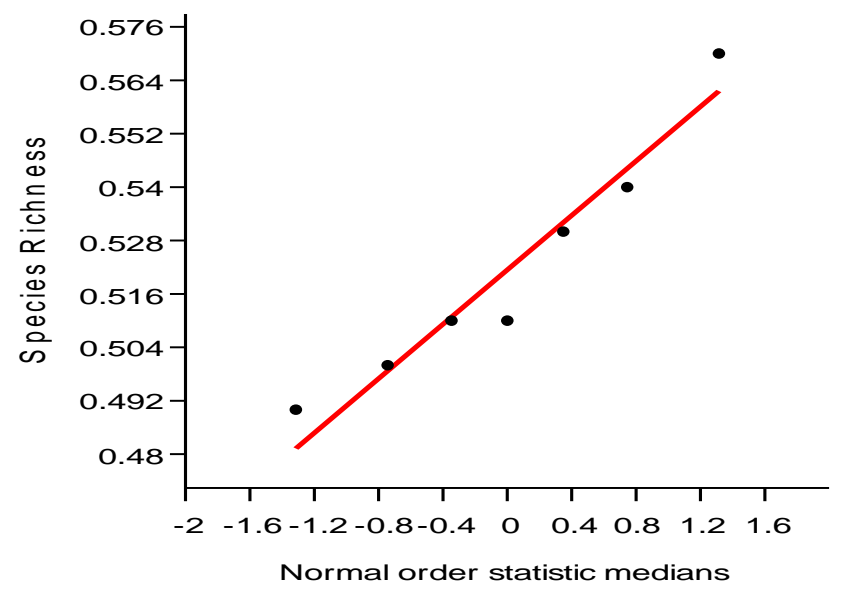

Figure 6. Dispersal species of $A$. ferox through NPC.

have potential for better performance in these sites (habitats) in the region and can be used for mass propagation/cultivation.

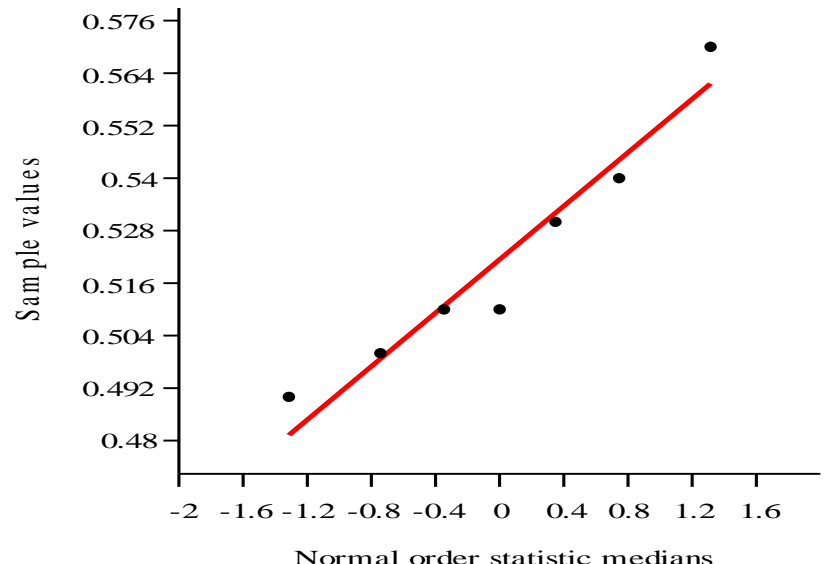

Figure 7. Dispersal species of $A$. heterophyllum through NPC.

\section{REFERENCES}

Airi S, Rawal RS, Dhar U, Purohit AN (2000). Assessment of availability and habitat preference of Jatamansi -A critically endangered medicinal plant of west Himalaya. Curr. Sci. 79:1467-1471.

Bhatt AB, Anil K, Rawal RS, Dhar U (2007). Assessment of status and biomass of Swertia angustifolia: a high value Himalayan medicinal plant. Afr. J. Plant Sci. 1(1):001-006.

CAMP (). CAMP Workshop, Shimla. 22-26 May 2003.

Cunningham WP, Saigo BW (1999). Environmental Sciences: A Global Concern. The McGraw-Hill Companies, Boston.

Curtis JJ (1959). The Vegetation of Wisconsin: An Ordination of Plant Communities. University of Wisconsin Press, Madison, Wisconsin.

Curtis JT, Mclntosh RM (1950). The interrelation of certain analytic and synthetic phytosociological characters. Ecology 31:434 455.

Hutchings MJ (1991). Monitoring plant populations: census as an aid to conservation. In: Goldsmith FB (ed.) Monitoring for conservation and ecology. Chapman and Hall, London.

IUCN (1993). Draft IUCN Red List Categories. Gland, Switzerland, IUCN.

Kala CP, Rawat GS, Uniyal VK (1998). Ecology and Conservation of the Valley of Flowers National Park, Garhwal Himalaya. Wildlife Institute of India, Dehradun.

Kaul MK, Handa SS (2001). Medicinal plants of crossroads of Western Himalaya. In: Samantl SS, Dhar U, Palni LMS (eds) Himalayan Medicinal Plants: Potential and prospects. Gyanoday Prakashan, Nainital.

Kershaw K A (1973). Quantitative and Dynamic Plant Ecology, Edward Arnold Ltd, London. p. 308.

Misra R (1968). Ecological Work Book. Oxford \& IBH Publishing Company, New Delhi.

Nautiyal BP (1996). Studies on Structure and Function in an Alpine Meadow of Garhwal, North West Himalaya. Ph.D. Thesis, HNB Garhwal University, Srinagar2003, Garhwal.

Nautiyal BP, Vinay P, Bahuguna MR, Bisht UH, Nautiyal MC (2002). Population study for monitoring the status of rarity of three Aconite species in Garhwal Himalaya. Trop. Ecol. 43(2):297-303.

Negi GCS, Rikhari HC, Singh SP (1992). Phenological features in relation to growth forms and biomass accumulation in an alpine meadow of the Central Himalaya. Vegetatio 101:161-170.

Pandey S, Well MP (1997). Eco-Development planning at India's Great Himalayan National Park for biodiversity conservation and participatory rural development. Biodiver.Conserv. 6:1277-1292.

Pangtey YPS, Samant SS (1988). Observation on the threatened, rare and endangered flowering plants and ferns in the flora of Kumaun Himalaya. Advances in Forestry Research in India 3:65-74.

Ram J, Arya P (1991). Plants forms and vegetational analysis of an alpine meadow of Central Himalaya, India. Proceeding of Indian National Science Academy 57:311-318.

Samant SS, Dhar U, Rawal RS (1993). Botanical hot spot of Kumaun 
Himalaya: Conservation perspectives. In: Dhar U. (ed.). Himalayan Biodiversity Conservation Strategies. Gyanodaya Prakashan, Nainital, pp. 377-400.

Samant SS, Dhar U, Rawal RS (1996a). Natural resource use by natives within Nanda Devi Biosphere Reserve in Western Himalaya. Ethnobotany 8: 40-50.

Samant SS, Dhar U, Palni LMS (1998). Medicinal Plants of Indian Himalaya: Diversity Distribution Potential Values. Almora: G.B. Pant Institute of Himalayan Environment and Development.

Shannon C, Wiener E (1963). The mathematical theory of communications. Univ. Illinois, Urbana, pp. 117. Simpson EH (1949). Measurement of diversity. Nature, 163-688.

Uniyal SK., Awasthi A, Rawat GS (2002). Current status and distribution of commercially exploited medicinal and aromatic plants in upper Gori Valley, Kumaon Himalaya, Uttaranchal. Curr. Sci. 82:1246-1252.

Ved DK, Kinhal GA, Ravikumar K, Prabhakaran V, Ghate U, Vijaya Shankar R, Indresha JH (2003). Conservation assessment and management prioritization for the Medicinal plants of Jammu and Kashmir, Himachal Pradesh and Uttaranchal. Foundation for Revitalization of Local Health Traditions, Bangalore, India.

Whittaker RH (1977). Evolution of species diversity in land communities. Evol. Biol.10, 1-67.cited in Magurran AE (2004). Measuring biological diversity, Blackwell Publishing: Oxford, UK.pp.-256.

\section{Notes}

HR21, Calculation of different aspects of diversity is related to threat assessment of the selected species.

HR22, Phytographs are used to define the exact phytosocilogical structure of the species in natural habitat by graphical representation.

HR23, \pm means standard deviation (Sd)

HR24, Total Basal Cover

HR25, Density- Density is a measurement of population per unit area or unit volume.

Abundance, The relative representation of a species in a community

HR27, Sample size is $1 \mathrm{X} 1$ meter mentioned in vegetation and sampling in material and method section.

HR30 \&HR31, $p$-value is given in the text as $p<0.001$. 